Jurnal Ilmu Olahraga Volume I Nomor 1 Oktober 2018

Y. Touvan Juni Samodra

Tersedia di: http://jurnal.untan.ac.id/index.php/jilo

\title{
EVALUASI PELAKSANAAN LATIHAN BEBAN PADA PERIODE PERSIAPAN TIGA CABANG OLAHRAGA DALAM PERSIAPAN PON BANDUNG 2016
}

\author{
Y. Touvan Juni Samodra \\ Prodi Pendidikan Kepelatihan Olahraga FKIP UNTAN \\ Email. touvansamodra@gmail.com
}

\begin{abstract}
Abstrak
Penelitian ini bertujuan untuk mengevaluasi pelaksanaan latihan beban pada periode persiapan tiga cabang olaharaga dalam persiapan PON bandung 2016. Sampel penelitian adalah cabang olahra panahan, tinju dan tarung drajat pelatih dan atlet. Data diperoleh dengan menggunakan angket. Hasil penelitian menunjukkan bahwa pada periode persiapan pada adaptasi anatomi cabang panahan dan tinju masih kurang dalam melakukan pembebanan kepada ateltnya. Pada periode peningkatan kekuatan maksimal cabang pahanan dan tinju terlalu over load memberikan beban kepada atlet yang dibinanya. Cabang tarung drajat dari awal menggunkan repetisi maksimal dalam melaksanakan pembebanan kepada atlet.
\end{abstract}

Kata kunci: latihan beban. PON

\section{WEIGHT TRAINING EVALUATION PREPARATION PERIOD OF THREE SPORTS FOR BANDUMG NATIONAL SPORT CHAMPIONSHIP 2016}

\author{
Y. TOUVAN JUNI SAMODRA \\ Sports Coaching Education Program FKIP UNTAN \\ Email. touvansamodra@gmail.com
}

\begin{abstract}
The aim of this research to evaluate weight training program for National sports championship 2016 (acher, boxing and tarung drajat muscle art). Samples are coaches and athletes of thee sports. Data were collected by questionnaire. Research show that in adaptation of anatomical archers and boxing were did under load. In strength period archers did over load to the athletes. Drajat muscle art used maximal repetition from the beginning of training as load for the athletes.
\end{abstract}

Key words: weight training, National sport championship. 


\section{Jurnal Ilmu Olahraga Volume I Nomor 1 Oktober 2018 \\ Y. Touvan Juni Samodra \\ Tersedia di: http://jurnal.untan.ac.id/index.php/jilo}

\section{A. PENDAHULUAN}

Perbedaan dalam melakukan latihan beban akan memberikan pengaruh yang berbeda pada atlet. Beberapa penelitian telah dilakukan kaitannya dengan hal tersebut, dinyakatan bahwa latihan yang lebih berat akan memberikan efek yang lebih baik, beberapa penelitian ini dinyatakan oleh (Campos GE et. All..2002; Holm L, Reitelseder S, Pedersen TG, Doessing S, Petersen SG, Flyvbjerg A, Andersen JL, Aagaard P, Kjaer M. 2008).

Penelitian yang dilakuka oleh peneliti-peneliti diatas juga di dukung oleh beberapa penelitian yang lain, hasi penelitian juga menunjukkan bahwa dengan latihan intensitas yang lebih tinggi akan terjadi peningkatan adaptasi otot yang lebih tinggi penelitian ini dilakukan diantaranya Mitchell, CJ, ChurchwardVenne, TA, West, DD, Burd, NA, Breen, L, Baker, SK, and Phillips 2012. Petunjuk baru dari penelitian yang dilakukan oleh Schoenfeld BJ (2013) menegaskan bahwa intensitas $65 \%$ adalah batas bawah bagi atlet yang ingin meningkatkan prestasi serta beban dengan intensitas inilah yang akam memberikan adaptasi positif terhadap otot. Sehingga berdasarkan beberapa penelitian diatas dapat disimpulkan bahwa latihan beban harus terukur dengan intensitas yang tepat dinyatakan bahwa $65 \%$ adalah batas ambang rangsang agar terjadi adapatasi pada otot.

Sejumlah penelitian menunjukkan bahwa latihan beban dapat meingkatkan hipertophy otot, dengan latihan ini telah tanpa melihat umur dan jenis kelamin ( Ivey et.all, 2000; Cosek et.all, 2006). Dalam penelitian selanjutnya dinyatakan bahwa beban yang lebih dari atau sama dengan $65 \%$ dari angkatan maksimal adalah beban yang cocok untuk meningkatkan hipertrophy otot, dan bahkan beban yang lebih dari $65 \%$ akan lebih baik untuk meningkatkan kekuatan maksimal (Kraemer and Ratamess, 2004; Kraemer et.all, 2002). Telah menjadi postulat bahwa semakin besar/berat beban yang diangkat maka memerlukan sejumlah keterlibatan otot sehingga juga akan meningkatkan ambang motor unit otot yang terlibat (Kraemer and Ratamess, 2004). Berdasarkan pada hal ini dapat disimpulkan bahwa ketika ingin meningkatkan kekuatan otot maka diperlukan beban yang lebih agar memaksa keterlibatan jumlah otot. Semakin banyak keterlibatan otot maka akan semakin banyak keterlibatan motor unit otot seingga hal ini akan memaksa sekelompok otot untk bekerja. Sekelompok otot yang bekerja ini terbagi dalam motor unit motor unit. Dengan pemahaman lain dapat dikatakan bahwa kekuatan akan besar ketika terjadi kerjsasama banyak motor unit.

Terdapat bukti penelitian baru yang menyatakan bahwa beban yang optimal disarankan antara 70\%-80\% dari angkatan maksimal, bukti penelitian lain memberikan gambaran bahwa latihan dengan beban rendah bahkan 30\% dapat meningkatkan kekuatan dan memiliki pengaruh yang sama dengan beban $70 \%$ $80 \%$ dengan catatan bahwa atlet melakukan beban tersebut dengan terlebih dahulu dibuat mengalami kelelahan (Burd et all, 2012).

Secara umum beban latihan dalam periodesasi latihan terbagi atas beberapa tahapan. Dalam tahap pertama pada adaptasi anatomi dilakukan dengan beban 65\%-75\%, tahap kekuatan maksimal antara $75 \%-100 \%$, tahap konversi tergantung dari kebutuhan kecabangan apakah daya tahan, kecepatan, power, power endurance. berdasarkan kaitan antara intensitas, repetisi, dan recovery. Semakin intensitas naik maka repetisi akan turun dan sebaliknya.

Berdasarkan pada beberapa penelitian dan teori yang diatas, Kalimantan Baran pada PON di Bandung 2016 mengikutsertakan kontingan PON. Peneliti meneliti bagaimana pelaksanaan 


\section{Jurnal Ilmu Olahraga Volume I Nomor 1 Oktober 2018 \\ Y. Touvan Juni Samodra \\ Tersedia di: http://jurnal.untan.ac.id/index.php/jilo}

program latihan beban beberapa kecabangan dari sudut pandang evaluasi. Lebih khususnya ketepatan dalam penyusunan dosis latihan terhadap atlet.

\section{B. METODE PENELITIAN}

Penelitian ini adalah penelitian evaluasi untuk menjelaskan pelaksanaan program latihan beban bagi para atlet PON Kalimantan barat. Sampel dalam penelitian ini adalah atlet dan pelatih olahraga tinju, tarung drajat dan panahan yang mengikuti PON pada 2016 yang diunggulkan. Data dikumpulkan dengan mengunakan angket. Angket disusun atas dasar kajian periodesasi latihan dan penerapan aplikasi di lapangan. Data dianalisis dengan menggunakan statistic deskriptif. Kajian evaluasi dilakukan untuk melihat kesesuain pelaksanana di lapangan dengan teori latihan.

\section{HASIL PENELITIAN DAN PEMBAHASAN}

\section{Hasil penelitian}

Berdasarkan angket yang telah dikembalikan ke peneliti, data penelitian dapat di deskripsikan dalam tabel 1 .

Bahwa pada berdasarkan pada intensitas yang dilaksanakan cabor tinju pada perode kondisioning menggunakan beban $65-75 \%$ dengan istirahat 1 menit antar alat, lebih dari 2 menit antar set dengan 6-8 alat dengan jumlah repetisi 3-4 repetisi. Pada cabor pahahan pada periode kondisioning menggunakan beban dengan intensitas 65-75\% dengan istirahat 1 menit antar alat, antara 2-3 menit antar set dengan 6-8 alat yang dipergunakan dengan jumlah repetisi $3-4$ repetisis. Cabang tarung drajat pembebanan adalah $65-75 \%$ dengan waktu isitirahat antar alat 1 menit, lebih dari 2 menit antar set menggunakan 6-8 alat dengan 8-12 repetisi.

Pada periode persiapan khusus cabor tinju melakukan pembebanan 80-90\% dengan 1 menit istirahat antar alat dan istirahat antar set menyesuaikan kondisi atlet, jumlah alat yang dipergunakan 9-10 alat dengan 8-12 repetisi. Cabor panahan pada persiapan khusus melakukan pembebanan $90 \%$ dengan lama istirahat antar alat 1 menit dan 2 lebih dari 2 menit antar set, alat yang dipergunakan 6-8 alat dengan 13-16 repetisi. Tarung drajat pada periode persiapan khusus menggunakan pembebanan repetisi maksimal dengan istirahat 1 menit antar alat dan lebih dari 2 menit antar set, alat yang dipergunakan adalah 6-8 alat dengan repetisi 13-16 repetisi.

\section{Pembahasan}

Berdasarkan pada data tersebut di atas maka dapat dianalisis dalam kerangka evaluasi pelaksanaan program latihan beban berdasarkan beberapa teori latihan. Analisis akan dilakukan atas dasar intensitas, waktu recovery, jumlah alat yang dipergunakan,serta jumlah repetisi yang dilakukan dengan pembagian atas dasar periode konsiioning dan periode persiapan khusus yang mana kedua periode ini masuk dalam periode persiapan.

\section{Periode kondisioning.}

a. Intensitas latihan

Pada periode adaptasi onatomi yang umumnya ada dalam periode kondisioning intensitas yang dilakukan adalah antara 65\%-75\%. Adaptasi anatomi dinyatakan oleh (2009: 22) begin with two or three workouts per week, using six to eight exercises over two or three sets of eight to 12 repetitions, and allowing two to three minutes' rest between sets. The loads should be between $65 \%$ and $75 \%$ of $1 R M$ and performed in circuit format. Dengan pernyataan ini jelas bahwa pada periode adaptasi anatomi beban yang dianjurkan adalah antara 65\%-75\% dengan dua atau tiga set dan melakukan repetisi atau angkatan sejumlah delapan sampai dua belas angkatan. Dianjurkan lagi latihan diberikan dalam format sirkuit. 
Tabel 1: Penerapan dosis latihan setiap siklus

\begin{tabular}{|c|c|c|c|c|c|c|}
\hline Olahraga & Periode & Intensitas & $\begin{array}{l}\text { lama } \\
\text { recovery }\end{array}$ & $\begin{array}{l}\text { istirahat } \\
\text { antar set }\end{array}$ & $\begin{array}{l}\text { jumlah } \\
\text { alat }\end{array}$ & $\begin{array}{l}\text { jumlah } \\
\text { repitisi }\end{array}$ \\
\hline \multirow[t]{2}{*}{ Tinju } & kondisioning & $65-75 \%$ & 1 menit & $<2$ menit & $6-8$ alat & $3-4$ repetisi \\
\hline & $\begin{array}{l}\text { persiapan } \\
\text { khusus }\end{array}$ & $80-90 \%$ & 1 menit & menyesuaikan & $\begin{array}{l}9-10 \\
\text { alat }\end{array}$ & $\begin{array}{lcl}8 & - & 12 \\
\text { repetisi } & \end{array}$ \\
\hline \multirow[t]{2}{*}{ Panahan } & kondisioning & $65-75 \%$ & 1 menit & 2 - 3 menit & $6-8$ alat & $3-4$ repetisi \\
\hline & $\begin{array}{l}\text { persiapan } \\
\text { khusus }\end{array}$ & $>90 \%$ & $<1$ menit & $<2$ menit & 6 - 8 alat & $\begin{array}{lll}13 \quad- & 16 \\
\text { repetisi } & \end{array}$ \\
\hline \multirow[t]{2}{*}{$\begin{array}{l}\text { Tarung } \\
\text { Drajat }\end{array}$} & kondisioning & $65-75 \%$ & 1 menit & $<2$ menit & $6-8$ alat & $\begin{array}{l}8 \quad- \\
\text { repetisi }\end{array}$ \\
\hline & $\begin{array}{l}\text { persiapan } \\
\text { khusus }\end{array}$ & reps. Mak & 1 menit & $<2$ menit & 6 - 8 alat & $\begin{array}{lll}13- & 16 \\
\text { repetisi } & \end{array}$ \\
\hline
\end{tabular}

Data menunjukkan bahwa intensitas yang dilaksanakan pada periode persiapan semua cabor menggunakan intensitas beban latihan $65-75 \%$. Secara teoritis berdasarkan pendapat diatas periode persiapan intensitas beban yang dilakukan sudah mengikuti aturan yang diberlakukan. Tujuan dari periode ini menurut Joe Friel's Adapt general body muscles and tendons to the stresses of strength training in preparation for the greater loading of the Maximum Strength (MS) phase to follow. Hal ini dapat dipahami bahwa pada masa adaptasi anatomi secara umum menyiapkan tubuh otot dan tendon-tendon untuk menerima beban latihan kekuatan sebagai persiapan untuk beban yang lebih tinggi yang akan dilakukan pada periode kekuatan maksimal. Sehingga pada periode adaptasi anatomi ini beban belum boleh pada beban maksimal, beban yang dianjurkan adalah beban pada intensitas $65 \%-75 \%$. Berapa lama waktu yang dibutuhkan dalam masa ini. Beberapa literature menganjurkan untuk periode satu puncak latihan diperlukan waktu sekitar 32 minggu sedangkan untuk dua puncak dalam satu tahun 13 minggi dan untuk tiga puncak dalam satu tahun lebih dari delapan minggu.

\section{b. Waktu recovery}

Waktu recovery merujuk pada berapa lama waktu yang diperlukan untuk istirahat antar alat dalam satu set latihan. Dalam satu set latihan dapat terdiri dari 616 alat. Setiap melakukan sejumlah angkatan maka diperlukan waktu tertentu untuk istirahat sebagai jeda perpindahan ke alat yang lain antara 1- 2 menit 30 detik. Berdasarkan data penelitian yang telah dilakukan ternyata ketia cabang olahraga tersebut menggunakan waktu recovery minimal 1 menit dan ada yang lebih. Sehingga dapat disimpulkan bahwa semua cabang olehaga melakukan waktu recovery dengan benar.

\section{c. Jumlah alat yang dipergunakan}

Mengacu pada tujuan adaptasi anatomi adalah untuk menyiapkan tubuh, otot, dan tendon agar siap menerima beban lebih pada periode latihan selanjutnya yaitu pada periode latihan kekuatan maksimal. Maka alat yang dipergunakan direkomendasikan adalah antara 12-16 alat. Dengan beban 65\%-75\% dari angkatan maksimal. Semakin sedikit persentase intensitas maka akan semakin besar jumlah 


\section{Jurnal Ilmu Olahraga Volume I Nomor 1 Oktober 2018 \\ Y. Touvan Juni Samodra \\ Tersedia di: http://jurnal.untan.ac.id/index.php/jilo}

angkatan yang harus dilakukan dan sebaliknya. Alat yang dipergunakan oleh ketiga cabang olahraga adalah 6-8 alat. Hal ini secara teoritis kurang tepat, akan tetapi ada kemungkinan hal ini dilakukan oleh pelatih karena masa persiapan yang diperlukan sebelum berangkat ke pecan olahraga nasional berkaitan dengan persiapan sangat minim. Sehingga jika menggunakan peralatan terlalu banyak maka akan terlalu membebani atlet. Pertimbangan kedua adalah atlet yang dilatih bukan lagi atlet pemula sehingga jumlah alat yang sedikit mengacu pada kebutuhan otot yang spesifik diperlukan untuk menunjang keberhasilan teknik. Alasan ketiga adalah dengan semakin sedikit peralatan yang dipergunakan maka otot khusus dipersiapkan lebih awal sehingga aka nada adaptasi yang lebih khusus mengingat kurangnya waktu persiapan.

d. Jumlah melakukan angkatan

Berdasarkan data yang telah terkumpul hanya cabang tarung drajat yang mendekati tepat dalam melatih jumlah angkatan kepada atletnya. Yaitu sejumlah 8-12 angkatan.

Seperti dinyatakan oleh Bompa (205: 147-150) dalam ilustrasi gambar memberikan gambaran bahwa semakin tinggi intensitas maka jumlah angkatan semakin sedikit dan semakin rendah maka jumlah angkatan semakin banyak. Jika beban rendah dan jumlah angkatan sedikit maka kurang akan terjadi adaptasi yang optimal dan sebaliknya jika beban persentase semakin tinggi tidak mungkin atlet dapat melakukan angkatan dalam jumlah yang banyak.

\section{Periode persiapan khusus.}

a. Intensitas latihan

Pada periode persiapan khusus ini focus latihan beban adalah untuk meningkatkan kekuatan maksimal. Ada banyak cara untuk meningkatkan kekuatan maksimal pertama dengan repetisi maksimal, angkatan makamial, dan pyramid. Cara repetisi maksimal merupakan latihan dengan cara menentukan satu beban tertentu dan atlet diminta untuk melakukan angkatan sampai tidak lagi mampu mengangkat, jumlah angkatan yang dilakukan adalah jumlah repetisi maksimal dalam beban tertentu. Berdasarkan pada beban tertentu ini dipergunakan untuk latihan atlet. Cara angkatan maksimal adalah dengan mengukur kemampuan atlet dalam satu beban yang hanya bisa diangkat oleh atlet hanya satu kali. Berdaarkan beban ini kemudian atlet melakukan latihan dengan mengangkat beban maksimal yang ditemukan berdasarkan tes yang dilakukan. Metode pyramid adalah dengan cara mengunakan beban yang bervariasi mulai dari $65 \%-100 \%$ disusun dalam beberapa tingkatan. Dobel pyramid merujuk pada pelaksanaan pyramid menaik dan menurun.

Beberapa saran untuk latihan beban yang dapat dijalankan adalah sebagai berikut:

1) Focus on the glutes, calf muscles, hamstrings and the muscles of the lower back, as strength in the posterior chain provides the foundation for athletic function.

2) Some upper body work needs to be carried out; in particular, the shoulders, triceps and abdominal muscles should not be neglected (obviously, if your sport requires great upper body strength - say, if you are a shot putter - then work should be done specifically on this area, with relevant weights exercises).

3) Strengthening the area around the shoulder joint helps to prevent injuries - for example, to the rotator cuff. Dislocations of the shoulder are fairly common in contact sports, particularly among amateur rugby players, and this is often a reflection of poor conditioning.

Bahwa latihan kekuatan harus mementingkan pada otot pantat, tungkai, 


\section{Jurnal Ilmu Olahraga Volume I Nomor 1 Oktober 2018 \\ Y. Touvan Juni Samodra \\ Tersedia di: http://jurnal.untan.ac.id/index.php/jilo}

togok, bahu. Hal yang terpenting adalah penguatan otot pada bagian persendiran untuk mencegah terjadinya cidera diskolasi (pergeseran sendi) terurama pada cabang olahraga yang memerlukan body kontek. Ditinjau dari intensitas latihan untuk peningkatan kekuatan maksimal beberapa cara dapata ditempuh. Athletes typically train with weights between $75 \%$ and $95 \%$ of IRM, and after a few weeks their IRM scores go up, which is great because it means they are stronger (John Shepherd, 2005: : 35). Lebih lanjut dikatakan bahwa As a guideline, elite levels of strength for a male athlete are 1RM squat of 2.5-3 $x$ body weight and 1RM bench press of 1.5-2 $x$ bodyweight, while those for a female are 2 and $1.25 x$ body weight respectively (John Shepherd, 2005: 40). Dapat dipahami bahwa latihan untuk meningkatkan kekuatan intensitas yang dipergunakan antara 75\%-100\%. Alternative lain adalah dengan berdasarkan pada berat badan sebaga contoh untuk atlet elit putra latihan squat adalah 2,5 kali berat badan latihan bench press 1.5 kali berat badan sementara untuk putri squat 2 kali berat badan dan bench press 1.25 kali berat badan. Berikut adalah contoh latihan pyramid menurut Bompa (2015: 147) untuk meningkatkan kekuatan maksimal.

Tabel 2:Jumlah repetisi berdasarkan intensitas latihan

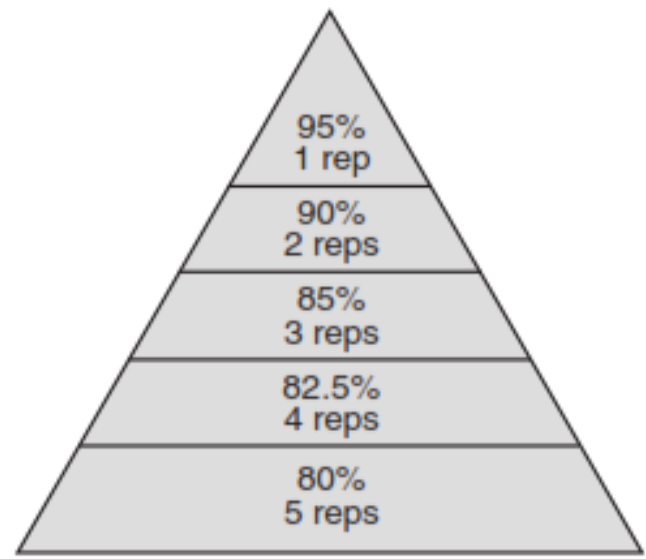

Data penelitian menunjukkan bahwa intensitas latihan untuk meningkatkan keuatan adalah antara $65 \%$ lebih dari $90 \%$. Dilihat dari intensitas latihan ketiga cabor melakukan latihan sesuai dengan dosis yang harus dilaksanakan.

b. Waktu recovery

Waktu recovery merujuk pada berapa lama waktu yang diperlukan untuk istirahat antar alat dalam satu set latihan. Dalam satu set latihan dapat terdiri dari 616 alat. Setiap melakukan sejumlah angkatan maka diperlukan waktu tertentu untuk istirahat sebagai jeda perpindahan ke alat yang lain antara 1- 2 menit 30 detik. Berdasarkan data penelitian yang telah dilakukan ternyata ketia cabang olahraga tersebut menggunakan waktu recovery minimal 1 menit dan ada yang lebih. Sehingga dapat disimpulkan bahwa semua cabang olehaga melakukan waktu recovery dengan benar. Berikut adalah contoh tabel intensitas, waktu istirahat antar interval dan antar set.

Tabel 3: dosis latihan

\begin{tabular}{|c|c|c|c|c|c|c|}
\hline $\begin{array}{c}\text { Intensity } \\
\text { zone }\end{array}$ & Load & $\%$ of IRM & $\begin{array}{l}\text { Concentric } \\
\text { failure } \\
\text { (no buffer) } \\
\text { or close to it } \\
\text { (low buffer) }\end{array}$ & $\begin{array}{c}\text { Rest interval } \\
\text { (minutes) }\end{array}$ & $\begin{array}{c}\text { Far from } \\
\text { concentric } \\
\text { failure } \\
\text { (high buffer) }\end{array}$ & $\begin{array}{c}\text { Rest } \\
\text { interval } \\
\text { (minutes) }\end{array}$ \\
\hline 1 & Supermax & $>105$ & \multirow{2}{*}{$\begin{array}{l}\text { Relative } \\
\text { strength }\end{array}$} & $4-8$ & - & - \\
\hline 2 & Max & $90-100$ & & $3-6$ & $\begin{array}{l}\text { Max strength } \\
\text { (90\%-95\% of } \\
\text { IRM) }\end{array}$ & $2-4$ \\
\hline 3 & \multirow[t]{2}{*}{ Heavy } & $85-90$ & Absolute & $2-4$ & \multirow{3}{*}{$\begin{array}{l}\text { Max strength } \\
\text { and power } \\
\text { (high load) }\end{array}$} & \multirow[t]{2}{*}{$2-3$} \\
\hline 4 & & $80-85$ & st & & & \\
\hline 5 & \multirow[t]{2}{*}{ Medium } & $70-80$ & Hypertrophy & $1-3$ & & \multirow[t]{3}{*}{$1-3$} \\
\hline 6 & & $50-70$ & \multirow{2}{*}{$\begin{array}{l}\text { Muscle } \\
\text { endurance }\end{array}$} & $0.5-2$ & \multirow{2}{*}{$\begin{array}{l}\text { Power } \\
\text { (low load) }\end{array}$} & \\
\hline 7 & Low & $30-50$ & & & & \\
\hline
\end{tabular}

Sumber (Bompa, 2015: 142)

c. Waktu istirahat antar alat

Waktu istirahat antar alat biasa disebut dengan waktu istirahat interval, berdasarkan tabel 3 diatas telah dicantumkan waktu yang optimal untuk istirahat baik itu antar alat ataupun antar set. Sebagai catatan bahwa rujukan waktu istirahat diatas adalah waktu istirahat yang dipergunakan untuk atlet elit, sehingga ketika ini diterapkan kepada atlet yang baru mulai latihan, maka waktu istirahat perlu 


\section{Jurnal Ilmu Olahraga Volume I Nomor 1 Oktober 2018 \\ Y. Touvan Juni Samodra \\ Tersedia di: http://jurnal.untan.ac.id/index.php/jilo}

ditambah lebih lama. Berdasarkan data penelitan yang diperoleh dari lapangan waktu istirahat antar alat maupuan antar set telah memenuhi seperti dalam teori latihan. d. Jumlah alat yang dipergunakan

Latihan peningkatan kekuatan secara teoritis lebih sedikit dari jumlah alat yang dipergunakan pada periode sebelumnya. Secara teoritis berkurang 20\%-25\% dari periode adaptasi anatomi. Alat yang dipiliah untuk peningkatan kekuatan maksimal adalah alat-alat yang menopang terhadap kebutuhan spesifik gerak dalam teknik kecabangan olahraga. Berdasarkan data yang diperoleh ternyata cabor tinju menggunakan alat lebih banyak dari periode sebelumnya dan cabor yang lain menggunakan alat dengan jumlah sama dengan periode adaptasi anatomi.

e. Jumlah melakukan angkatan

Jumlah angkatan dalam latihan kekuatan maksimal tergantung dari cara yang dipergunakan untuk menigkatkan keuatan maksimal. Jika peningkatan kekuatan dengan repeteisi maksimal maka jumlah angaktan yang dipergunakan adalah sampai atlet tidak mampu melakukan angkatan. Jika mengunakan metode piramida maka jumlah angkatan akan menyesuaian terhadap intensitas persentase yang dipergunakan. Semakin besar intensitasnya semakin sedikit jumlah angatannya. Sebaga contoh sebagai berikut:

Tabel 4: Hubungan antara angkatan maksimal dengan jumlah angkatan yang mampu dilaksanakan

\begin{tabular}{|c|c|}
\hline$\%$ & Neuromuscular \\
\hline RM & Efficiency Athlete (Power) \\
\hline 100 & 1 \\
\hline 95 & $1-2$ \\
\hline 90 & 3 \\
\hline 85 & 5 \\
\hline 80 & 6 \\
\hline 75 & 8 \\
\hline 70 & 10 \\
\hline 65 & 15 \\
\hline 60 & 20 \\
\hline
\end{tabular}

\begin{tabular}{cc}
\hline 50 & $25-30$ \\
40 & $40-50$ \\
30 & $70-100$ \\
\hline & Sumber (Bompa, 2015: 138)
\end{tabular}

Berdasarkan data yang telah terkumpul hanya cabang tarung drajat yang mendekati tepat dalam melatih jumlah angkatan kepada atletnya. Yaitu sejumlah 8-12 angkatan. Seperti dinyatakan oleh Bompa (2015: 147-150) dalam ilustrasi gambar memberikan gambaran bahwa semakin tinggi intensitas maka jumlah angkatan semakin sedikit dan semakin rendah maka jumlah angkatan semakin banyak. Jika beban rendah dan jumlah angkatan sedikit maka kurang akan terjadi adaptasi yang optimal dan sebaliknya jika beban persentase semakin tinggi tidak mungkin atlet dapat melakukan angkatan dalam jumlah yang banyak.

\section{KESIMPULAN DAN SARAN \\ 1. Kesimpulan}

Berdasarkan pada data penelitian dan pembahasan di atas dapat disimpulkan beberapa hal. Bahwa untuk periode kondisioning yang isinya adalah latihan adaptasi anatomi cabang panahan dan tinju masih kurang dalam melaksanakan jumlah angkatan. Pada periode peningkatan kekuatan maksimal cabang tinju dan pahanan terlalu banyak melakukan repetisi angkatan beban.

\section{Saran}

Khusus kedua cabor tinju dan pahanan agar mereview kembali data atlet perihal angkatan maksimal yang dapat dilakukan atlet, mengingat data ini penting untuk menentukan beban yang sesuai agar tidak terjadi over training.

\section{Daftar Pustaka}

Bompa, G. Gregory Haff . 2009.

Periodization: theory and 
methodology of training. Human kinetic. USA

Bompa. 2015. Periodiation training of sport. Human kinetic. USA

Burd, NA, Mitchell, CJ, ChurchwardVenne, TA, and Phillips, SM.2012. Bigger weights may not beget bigger muscles: evidence from acute muscle protein synthetic responses after resistance exercise. Appl. Physiol. Nutr. Metab. 37: 551-554, 2012.

Campos, GER, Luecke, TJ, Wendeln, HK, Toma, K, Hagerman, FC, Murray, TF, Ragg, KE, Ratamess, NA, Kraemer, WJ, and Staron, RS. 2002. Muscular adaptations in response to three different resistance-training regimens: specificity of repetition maximum training zones. Eur. $J$. Appl. Physiol. 88: 50-60,.

Holm, L, Reitelseder, S, Pedersen, TG, Doessing, S, Petersen, SG, Flyvbjerg, A, Andersen, JL, Aagaard, P, and Kjaer, M. 2008. Changes in muscle size and mhc composition in response to resistance exercise with heavy and light loading intensity. J. Appl. Physiol. 105: 1454-1461,.

Ivey, FM, Roth, SM, Ferrell, RE, Tracy, BL, Lemmer, JT, Hurlbut, DE,
Martel, GF, Siegel, EL, Fozard, JL, Jeffrey Metter, E, Fleg, JL, and Hurley, BF. 2000. Effects of age, gender, andmyostatin genotype on the hypertrophic response to heavy resistance strength training. $J$. Gerontol. A Biol. Sci. Med. Sci. 55: M641-8,

Joe Friel's Anatomical Adaptation (AA) Phase. http://help.trainingpeaks.com/hc/enus/articles/204072054-Joe-Friel-sAnatomical-Adaptation-AA-Phase Kraemer WJ, Adams K, Cafarelli E, et al. American College of Sports Medicine position stand. Progression models inresistance training for healthy adults. Med Sci Sports Exerc 2002;34:364-80.

Mitchell CJ, Churchward-Venne TA, West DW, Burd NA, Breen L, Baker SK, Phillips SM.. J. Appl. Physiol. 113, 71-77, 2012

Schoenfeld BJ. Does exercise-induced muscle damage play a role in skeletal muscle hypertrophy? JStrength Cond Res 26: 1441-1453, 2012. 
Jurnal Ilmu Olahraga Volume I Nomor 1 Oktober 2018

Antonius S, Belka Farlin, M.Suprayogi, Thoribius R, Nopensah, Reza \& Bardiono Tersedia di: http://jurnal.untan.ac.id/index.php/jilo 